UNITED STATES DEPARTMENT OF THE INTERIOR GEOLOGICAL SURVEY

\title{
Metropolitan San Francisco and Los Angeles \\ Earthquake Loss Studies: \\ 1980 Assessment
}

\author{
By \\ Steinbrugge, Kar1 V., Algermissen, S. T., Lagorio, Henry J., \\ Cluff, Lloyd S., and Henry J. Degenkolb
}

Open-File Report $81-113$

This report is preliminary and has not been edited or reviewed for conformity with U.S. Geological Survey standards and nomenclature. 


\author{
Copies of this Open-File Report \\ may be purchased from \\ Open-File Services Section \\ Branch of Distribution \\ U.S. Geological Survey \\ Box 25046, Federal Center \\ Denver, Colorado 80225
}

\title{
PREPAYMENT IS REQUIRED
}

Price information will be published

in the monthly listing

"New Publications of the Geological Survey"

FRONT COVER:

The Hibernia bank building.

1906 San Francisco, California earthquake

Photograph by W.C. Mendenhall

BACK COVER:

East side of Howard Street near Seventeenth Street.

The three-story house dropped from its south foundation

wall and leaned against its neighbor.

1906 San Francisco, California earthquake

Photograph by G.K. Gilbert 
METROPOLITAN SAN FRANCISCO AND LOS ANGELES EARTHQUAKE LOSS STUDIES:

1980 ASSESSMENT

by

Karl V. Steinbrugge

S. T. Algermissen

Henry J. Lagorio

Lloyd S. Cluff

Henry J. Degenkolb

\section{Introduction}

This report was prepared as a result of the President's request that his Science Advisor, Dr. Frank Press, conduct a review of disaster preparedness for and consequences of a major California earthquake. The review has been carried out through an ad hoc committee of the National Security Council. This report is a contribution to that review.

Consequences of the maximum probable earthquake to occur on each of two faults in each of the metropolitan Los Angeles and San Francisco areas were developed in two reports prepared, in part, by the authors in 1972 and 1973; these reports evaluated the probable number of casualties and those left homeless, together with effects to selected important facilities, and economic 1oss.

"A Study of Earthquake Losses in the San Francisco Bay Area", A Report Prepared for the Office of Emergency Preparedness by the National Oceanic and Atmospheric Administration (NOAA), 1972.

"A Study of Earthquake Losses in the Los Angeles, California, Area", A Report Prepared for the Federal Disaster Assistance Administration, Department of Housing and Urban Development by N`AA, 1973.

Henceforth these two reports will be cited as the NOAA studies and reports.

Steinbrugge, Kar1 V., Structural Engineer, E1 Cerrito, California; Algermissen, S. T., Research Geophysicist, U.S. Geological Survey, Denver, Colorado; Lagorio, Henry J., College of Environmental Design, University of California, Berkeley, California; Cluff, Lloyd S., Woodward Clyde Consultants, San Francisco, California; Degenkolb, Henry J., Degenkolb and Associates, San Francisco, California. 
Since the publication of the NOAA reports, continued inflation, urban redevelopment, and population growth have resulted in changes to the original source data and to the inventories in these two metropolitan areas. It was appropriate to review these inputs to determine what might be required for an update of the previous findings, and then to implement the update.

This report is in two parts. Part A relates to casualties, homeless, and effects to certain disaster-response capabilities. Part A should be used in conjunction with the two previously cited studies for clarity and continuity. The expected monetary losses in the event of the same or similar postulated earthquakes considered in the two NOAA reports is also estimated. Part B discusses the estimated direct economic losses which might be expected in the event of any of the four postulated earthquakes.

The findings of this report were originally submitted in draft form to meet the deadline of the ad hoc committee of the National Security Council. The purpose of this more formal report is to present the previously submitted information in a format suitable for wider distribution and also in a form that is more useable for application to disaster-response planning. To do this, the numbers on casualties and monetary losses have been re-examined in somewhat greater detail than those given for the original submission. However, the findings given herein differ only negligibly with those previously presented, and then only with respect to casualties and homeless when broken down to county or sub-coun'y. Dwelling monetary losses have been added. 


\section{PART A}

CASUALTIES, HOMELESS, AND DAMAGE

The two study areas for this report remain unchanged from those used in the NOAA reports and are restated here for convenience. They are also shown in Figures 1, 2, and 3.

1. Metropolitan San Francisco Area:
Alameda County
Contra Costa County
Marin County
Napa County
San Francisco County
San Mateo County
Santa Clara County
Solano County
Sonoma County

2. Los Angeles and Orange Counties, except that the counties of Riverside, San Bernardino, and Ventura were added for the inventory of hospitals only.

The same maximum probable earthquakes selected for the NOAA reports were used for the purpose of updating, although the magnitude 7.5 is now considered to be the maximum probable size for the Hayward fault. All magnitudes in this report are $M_{S}$ (surface wave) magnitudes. In addition, it was convenient to again include the effects for earthquakes less than the maximum probable in northern California. The probable earthquakes evaluated were:

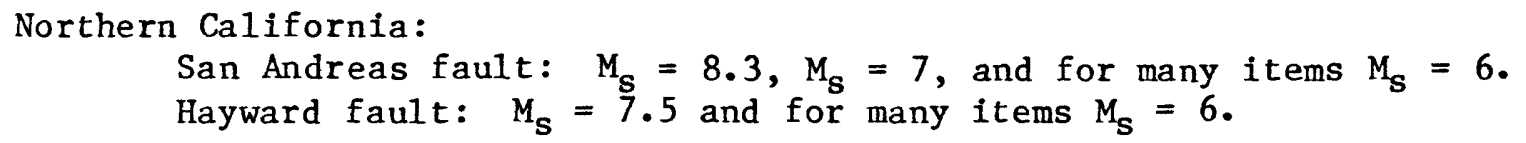

Southern California:

San Andreas fault: $M_{S}=8.3$

Newport - Inglewood fault: $M_{S}=7.5$

The scope of the updating did not include any significant amounts of field effort directed towards the re-examination of inventories, except for an overview of dams. The source data for the two NOAA reports were reviewed and in general they were found to remain reasonably adequate when extrapolated on 
the basis of population changes. Time constraints did not allow the use of more sophisticated extrapolation methods. Principal sources of new and revised information for this updating were as follows:

Demographic and Inventory Updating Sources:

1. Association of Bay Area Governments (ABAG), Bay Area Council, Berkeley, California

2. The Regional Planning Commission, County of Los Angeles, Los Angeles, California.

3. Security Pacific National Bank, Research Department, San Francisco and Los Angeles, California.

4. Marketing Research Department, Los Angeles Times, Inc., Los Angeles, California.

5. Department of Finance, Population Research Unit, Sacramento, California.

Reservoir and Dam Updating Sources:

1. Office of Emergency Services, Planning and Operations, Sacramento, California.

2. Resources Agency, Department of Water Resources, Sacramento, California.

3. City of Los Angeles, Department of Water and Power, Los Angeles, California.

Major Hospital Updating Sources:

1. Department of Health, State of California, Sacramento, California.

2. Office of the State Architect, Department of General Services, Sacramento, California. or both.

Personnel in the foregoing offices were contacted in person or by phone, Several were contacted more than once. 


\section{Demographic Changes and Their Applications}

A basic assumption was made that residential population changes were proportional to building inventory changes between the 1972/73 NOAA reports and 1980. As a corollary, we also assumed that the percentage change in inventory by class of construction would parallel population change. (Class of construction is correlatable with earthquake-caused deaths and injuries as well as building damage.) Population change as indicated by class of construction would be reflected in mercantile occupancies,' particularily shopping centers vs. population growth. We further presumed that industrial growth would be proportional to population growth. This may be questioned in some areas where the industrial lands have become fully developed and their occupancy remains constant, but nearby populations might have changed in either direction. Other exceptions exist, such as office buildings in downtown San Francisco which may not accurately reflect population change. For another example, because of declining birth rates, the public school population is not growing; indeed, some schools have been closed. Therefore, the inventory of school buildings remains essentially unchanged from those used in previous studies even though the population distribution around the schools has changed slightly. New major hospitals reflect improved State of California laws enacted since the San Fernando 1971 shock. Although these new hospitals are limited in number, they do represent improved situations since they were designed to remain functional after she shock insofar as practical. While there has been substantial growth in both metropolitan areas, particularly in the outlying developing communities, in our judgment it has not been sufficiently out-of-proportion to population growth or to changes in construction characteristics to warrant alternative 
extrapolation methods. In summary, population extrapolation methodology was used, modified by judgment based on personal knowledge of changes in regional conditions.

The results of the 1980 Census are not yet available. However, acceptable population data are constantly being gathered by the State of California, with the latest available being those of the January 1, 1980 . Based on this information for each study area, overall population has increased by about 10\% since the 1972 and 1973 reports were prepared (these previous reports used the 1970 Census). In detail, the growths were not uniform within either study area.

Table 1 shows current population data for the San Francisco metropolitan area, Table 2 is for Los Angeles and Orange Counties. In the previous NOAA study, Los Angeles County had been subdivided into 9 areas (Figure 3) which did not exactly coincide with all political boundaries; a nominal amount of data extrapolation was required to obtain the populations for Los Angeles and Orange Counties given in Table 2. A comparative examination with the previous Los Angeles study will show that some areas have declined in population. Tables 3, 4, and 5 give the estimated 1980 population of major cities in the two study areas.

\section{Reassessed Results Exclusive of Dams}

Reassessed results for a number of catagories covered in the NOAA studies are given in Tables 6 through 21 and are listed below:

Metropolitan San Francisco Area:

Table 6: Deaths and Hospitalized Injuries

Table 7: Non-Hospital Clinical Laboratories

Table 8: Transportation Problems and Their Effects on Medical Personnel

Table 9: Ambulance Service Impairment

Table 10: Nursing Homes and Related Facilities

Table 11: Long Term Homeless 
Table 12: Inventory of Major Hospitals

Table 13: General Hospital Bed Loss

Metropolitan Los Angeles - Orange Counties:

Table 14: Deaths and Hospitalized Injuries

Table 15: Non-Hospital Clinical Laboratories

Table 16: Deaths to Health Manpower

Table 17: Ambulance Service Impairment

Table 18: Nursing Homes

Table 19: Long Term Homeless

Table 20: Inventory of Major Hospitals

Table 21: General Hospital Damage

Results shown in these tables are extrapolations on the basis of population changes, modified by information gained from the previously cited sources and further modified judgmentally from personal knowledge gained by field inspections and from other sources. Exposure in "Nursing Homes" has increased because there are more homes, in turn because 1ife expectancy of the general public has been prolonged on the average. Data on "Public Schools", "Bloodbanks", "Public Utilities", and "Fire Following Earthquake" remain essentially unchanged and therefore are not repeated here. "Communications" and "Transportation" were excluded from this study since they were to be evaluated by others. Items such as the "HRDI Modules" and "PDH Units" were no longer considered since they were phased out in 1973.

Bed capacity data for all major general hospitals were collected for all hospitals with 99 beds or more in the San Francisco Study Area and the Los Angeles Study Area (expanded to include three additional counties of Riverside, San Bernardino, and Ventura). Bed data on military hospitals and Veterans Administration Hospitals were not readily available and are therefore not included due to time constraints.

Scenarios and supplemental data obtained from the original reports may be modified as required by Tables 6 through 21 . 
Dams and Reservoirs

Since publication of the previous studies, legislation on the safety of downstream populated areas below dams under State of California jurisdiction has been mostly implemented. State-approved inundation maps are on file at the Office of Emergency Services (OES) in Sacramento, California. These maps designate areas "within which death or personal injury would....result from partial or total failure of a dam". Legislation also stated that OES "shall review such procedures to determine whether adequate public safety measures exist for the evacuation and control of populated areas below the dams, and shall make recommendations with regard to the adequacy of such procedures to the concerned public safety agency..."

Updated state-compiled data were reviewed. As in the original studies, federally owned dams were not included in the review since at that time it was judged that they did not pose a significant life hazard in the two study areas.

Copies of all inundation maps for the dams and reservoirs listed in Tables 22 and 23 were received from OES except for Calaveras and San Andreas Dams in the San Francisco area and Chatsworth Dam in the Los Angeles area. (Chatsworth Reservoir is currently empty.) Figures 3 an 4 give the locations of all major dams and reservoirs. All dams and reservoirs listed in Tables 22 and 23 were either looked at in July of 1980 or personal knowledge made it unnecessary to do so.

Since publication of the previous reports, many of the water storage dams listed in Tables 22 and 23 have been re-evaluated for seismic stability using the latest analytical methods. Those dams that were assessed to be hazardous have been, or will be, modified to conform to the currently required standards of safety. For example in the San Francisco area, the San Leandro Dam has 
been completely rebuilt and the San Pablo Dam has been substantially improved. Chabot Dam is being reconstructed at this writing. In the Los Angeles area, Lower Franklin Reservoir has been drained and the dam is no longer in operation; bids are currently being advertised for a reconstruction contract in late 1980. Fairmont Dam has been operated at a reduced water level since 1966 and a construction contract for a new dam and reservoir is anticipated to be let in 1981. Thus, the probability of dam failure has been significantly reduced since publication of the earlier studies.

It is very reasonable to assume that the recently constructed major dams and those which have been modified in recent years have incorporated adequate seismic safety criteria. However, the consequence of error may be very significant. Therefore, for disaster planning purposes only, the number of probable homeless and dead resulting from a failure of a dam is given in Tables 24 and 25. Also for planning purposes, at most one dam failure should be considered even though it is not a probable event. The selected dam may be chosen on a random basis. All of the tabled loss figures represent the worst risk conditions based on generalized assumptions regarding inundation areas, rates of flow, and similar criteria.

\section{PART B \\ MONETARY LOSSES}

The study areas for monetary losses were the same as those used in Part A, except that the area in southern Califnrnia was extended to include the counties of San Bernardino, Kern, Riverside, and Ventura with those of Los Angeles and Orange. The subject matter in Part B has been expanded using unpublished information, except that the dwelling information was updated from previously published studies. Monetary losses were not extensively covered in the two NOAA studies. 
The same earthquakes and causative faults were used for the monetary loss studies (Part B) as for those for casualties (Part A).

\section{Source Materials}

Required source data must include the magnitudes of the postulated earthquakes, locations of the earthquakes on causative faults, the isoseismals (expected damage patterns as a function of distance from the fault), the dollar quantification of the damage patterns by class of building construction, and dollar loss summation.

The source materials with respect to losses should be selected so as to appropriately reflect losses that will be useful to the user, i.e. public organizations. Therefore, an "impersonal loss" definition must be used. Impersonal loss is taken to mean a loss to be paid by others and not by the individual or organization involved. For example, a dent in an automobile fender, if not covered by insurance, may not be repaired and the owner may consider it negligible although somewhat unsightly; the owner probably would have a different viewpoint if an insurance policy covering this loss had been purchased. Similarly, minor earthquake cracking in the plastered or gypsumboard wa1ls of wood frame dwellings cannot be considered as a life hazard, albeit unsightly. The owner may repaint the walls for $\$ 50$ by doing the work himself; this "personal" loss might be placed at $\$ 50$ since only outof-pocket expenses were considered. If, however, the repainting was done by professionals, perhaps $\$ 500$ would be involved. The monetary losses in this study are considered on an impersonal basis in order to provide consistency and also provide a guide to cost should government become involved in repairs or replacement. 
Monetary source data in northern California was carefully considered. Twenty sources were examined, including those of the California Board of Equalization and those of the county assessors of the 9 counties in the San Francisco Bay Area; all were fruitless. Assessor data are often regarded to be potentially superior sources: the following is quoted from a Steinbrugge and Lagorio report (1975):

"Dollar value data for improvements on land were received from each county assessor's office in the test area. When correlated with use code designations, improvement values for individual counties could be classified for some specific occupancies but normally not with construction classes. Therefore, data commonality throughout the test area did not exist, and judgmental interpretations are required for summing total regional values for any occupancy. Further interpretations are required for relationships to construction classes..."

"There is virtually no consistency among assessors' offices in the methods used in reporting statistics for specific classes of buildings. Appraisal of residential property occurs on a different basis than commercial or industrial developments...."

"In conclusion, while assessor data provide an excellent source of dollar values, they are gathered on a different basis in each county, are not adequately segregated by construction class...."

* Steinbrugge, K. V., and Lagorio, H., 1975, Building classifications and relationships among losses, intensities, and classes: Report to U.S. Geological Survey, v. 1, $88 \mathrm{p}$, and appendices. 
The method used in this study has been to survey unpublished fire insurance data and adapt them to earthquake useage. These data required interpretation by the authors based, in part, on the knowledge developed during the preparation of the two aforementioned NOAA studies.

Computational Methodology

The initial data were fire insurance property values by county for northern California and an assumed 8.3 magnitude earthquake on the San Andreas fault. These values included dwellings, commercial buildings, manufacturing plants, warehouses, offices, and all other fire-insured properties. These property values were increased to include non-insured private property as well as increased to include under-insured property. Adjustments were made on a judgment basis to include the value of Federal, State of California, and local government-owned buildings. Intensities from the NOAA reports isoseimal maps were converted into loss factors, or the percent loss based on an impersonal definition basis. These percentages were multiplied by the property values to obtain the total impersonal loss by county in the study area, then summed to obtain the total aggregate loss. In this process, values were adjusted to compensate for inflation to 1980.

Building contents for the aforementioned San Andreas earthquake were analyzed in a similar manner to derive the total contents aggregate loss. Loss computation methodology for a major earthquake on the Hayward fault followed the same computational patterns as those for the San Andreas fault. Southern California provided a different problem in that basic insurance data had not been developed. However, a first-order estimate can be made by extrapolations based on population differences and estimated differences in the geographic distribution of the buildings by class of construction. 
Dwellings

Methodologies for determining dwelling losses may be found in"

"Studies in Seismicity and Earthquake Damage Statistics, 1969", plus Appendices A and B in separate volumes. A report prepared by Environmental Science Services Administration, U.S. Department of Commerce, 1969.

"Estimation of Earthquake Losses to Single Family Dwellings", by W. Rinehart, S. T. Algermissen, and Mary Gibbons. USGS Open File Report No. 76-156, 1976.

A number of supplemental or related unpublished reports exist.

The computational methodology was to update residential values increased by inflation from those values determined in previous studies using replacement values (i.e., excluding land values). Loss factors as a function of isoseismal maps prepared by the USGS were next applied, with results as indicated in the next section.

\section{Findings}

The findings are summarized in Table 26. The "Total Loss" figures do not include transportation or communication systems, do not include dams or military installations, and do not include consequential loss such as unemployment, loss of taxes, shutdown of factories outside of California due to loss of supplies (such as might happen in the electronics industry), and automobile damage. "Dwelling Loss" is a component of "Total Loss", and should not be added again to the total.

"Total Loss" and "Dwelling Loss" figures were derived from different data bases and partially different methodologies. A comparison between results, however, appears to be reasonable. 


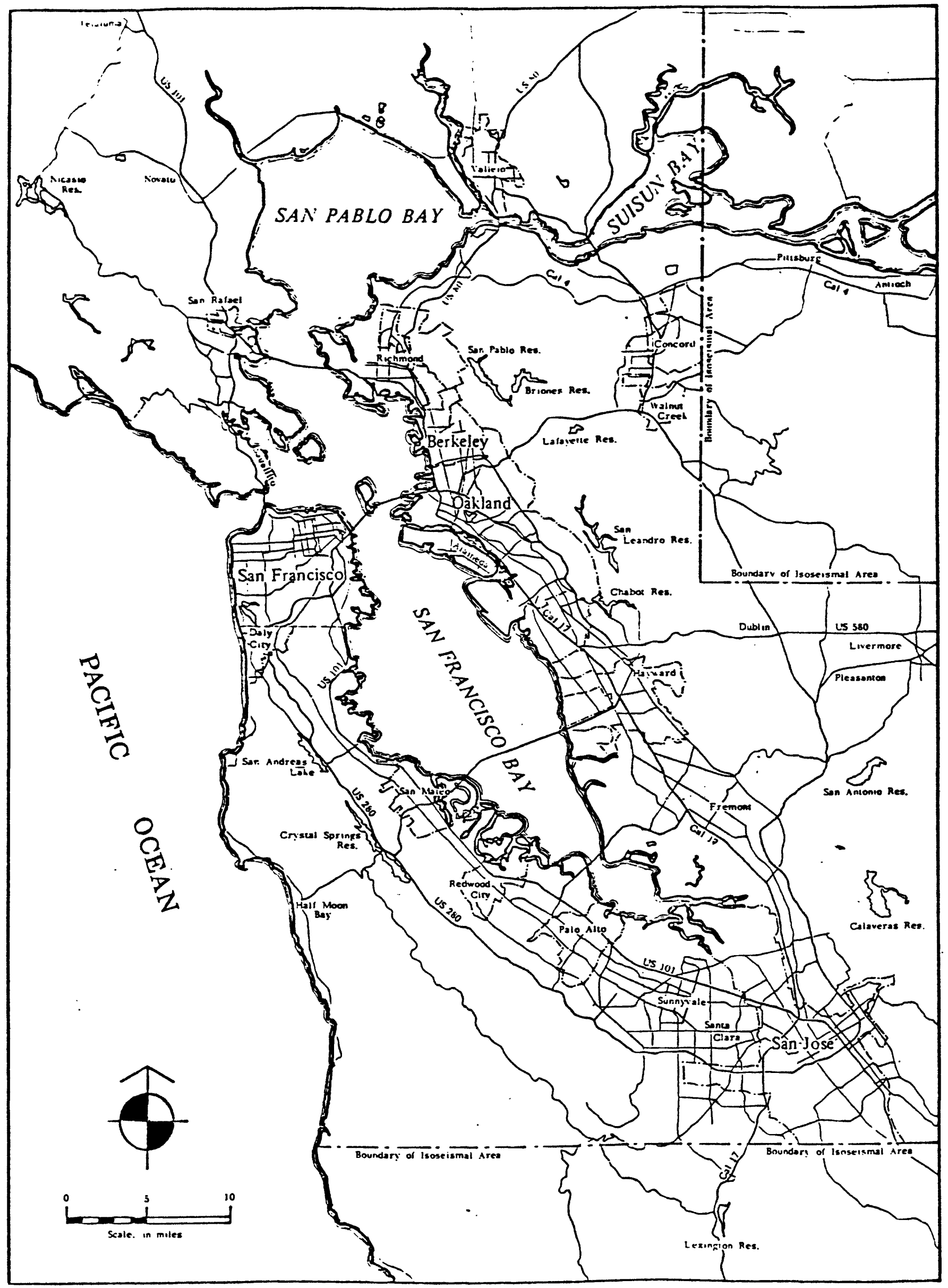

FIGURE 1. Metropolitan San Francisco Study Area. 


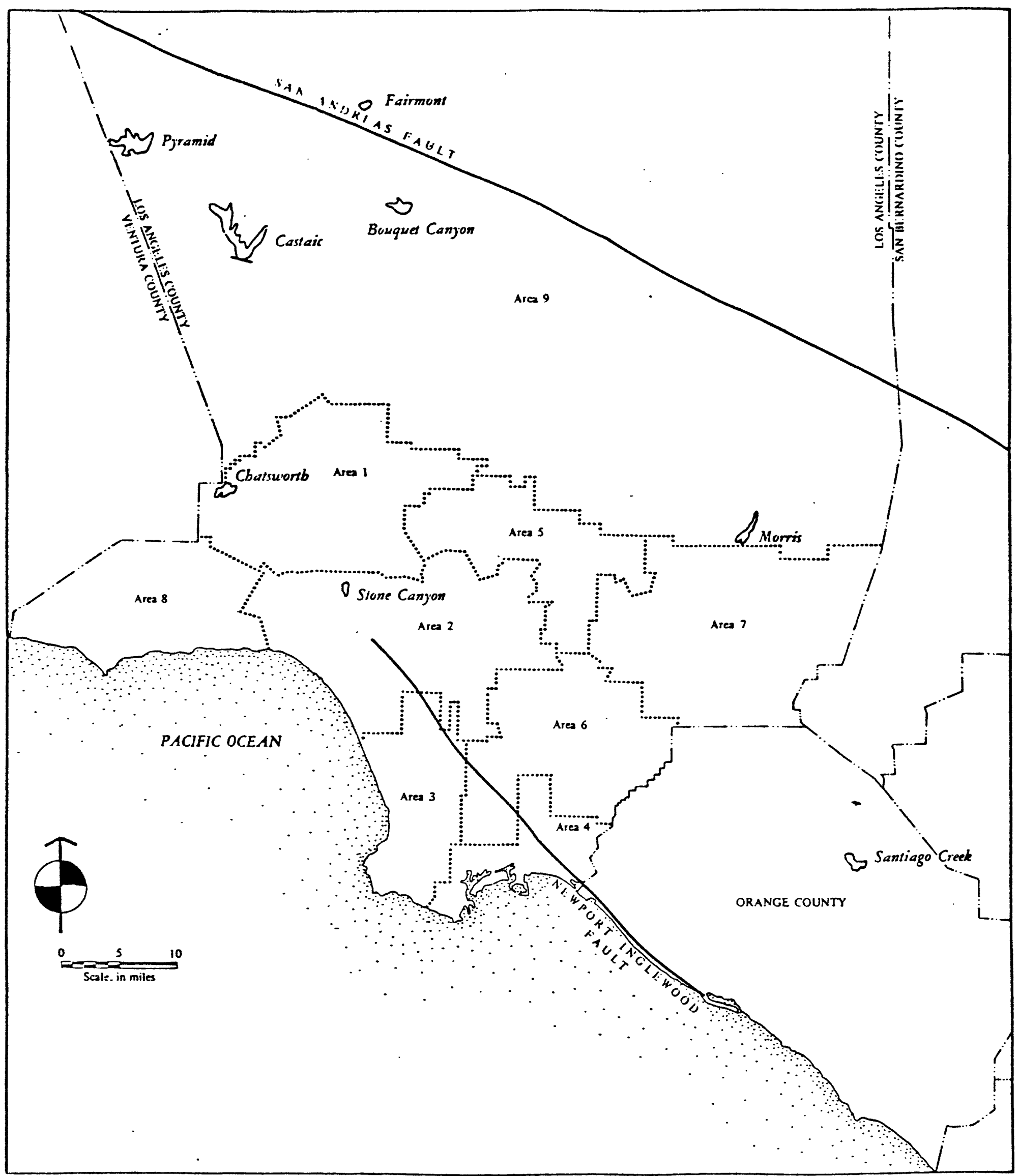

FIGURE 3. Los Angeles and Orange Counties showing reservoirs and 9 study areas within Los Angeles County. 


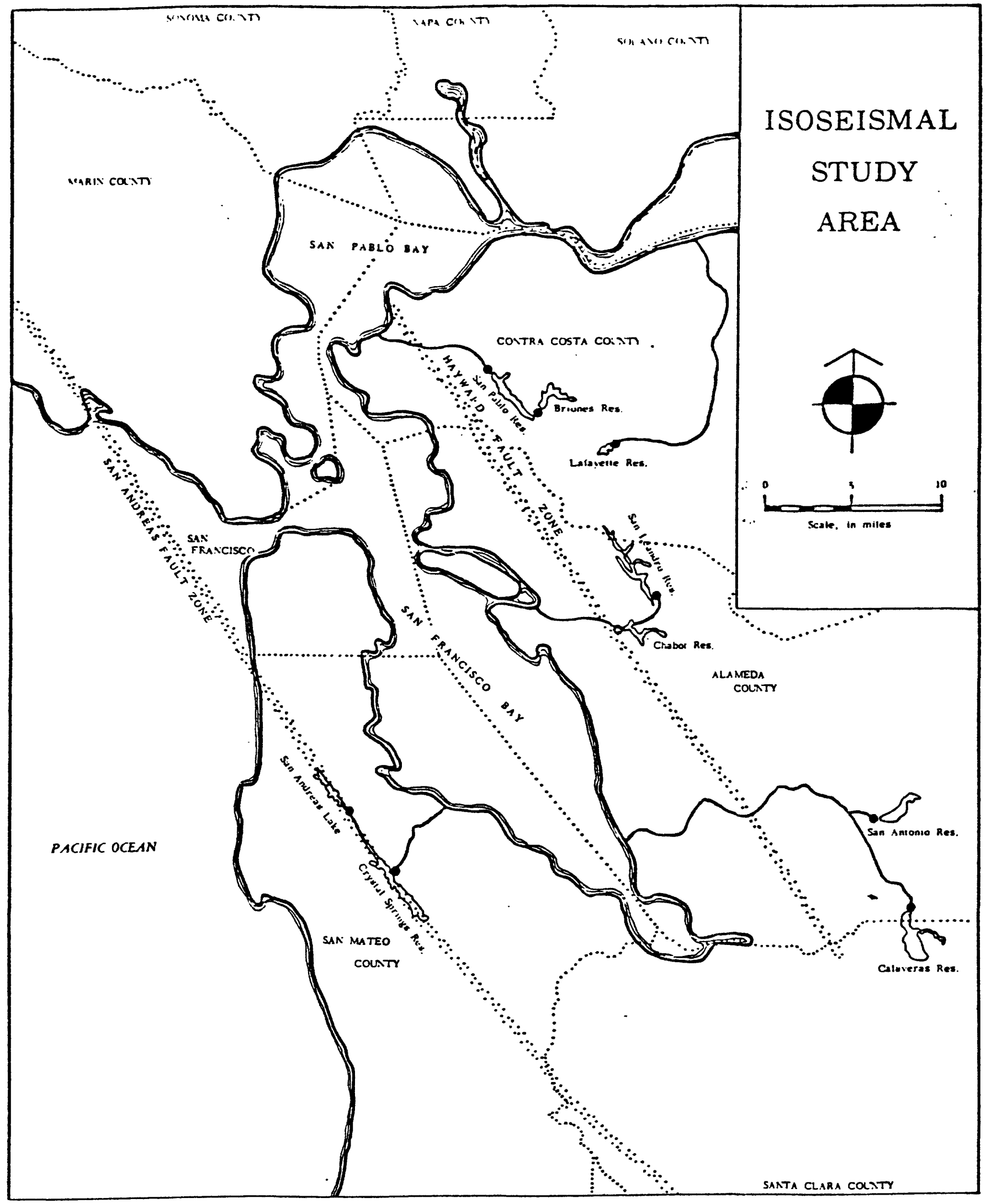

FIGURE 4. Dams and reservoirs in the San Francisco study area. 
Table 1.--Population of San Francisco study

area as of January 1,1980

\begin{tabular}{lc} 
County & Population \\
\hline Alameda & $1,098,500$ \\
Contra Costa & 645,300 \\
Marin & 225,200 \\
Napa & 93,400 \\
San Francisco & 642,900 \\
San Mateo & 589,200 \\
Santa Clara & $1,265,200$ \\
Solano & 225,500 \\
Sonoma & 284,400 \\
\hline
\end{tabular}

Source: "Population Estimates of California Cities and Counties", Report 80 E-1, Population Research Unit, Department of Finance, State of California. May 1, 1980. Sacramento, California. 

Table 2.--Population of Los Angeles and Orange Counties as of January 1,1980

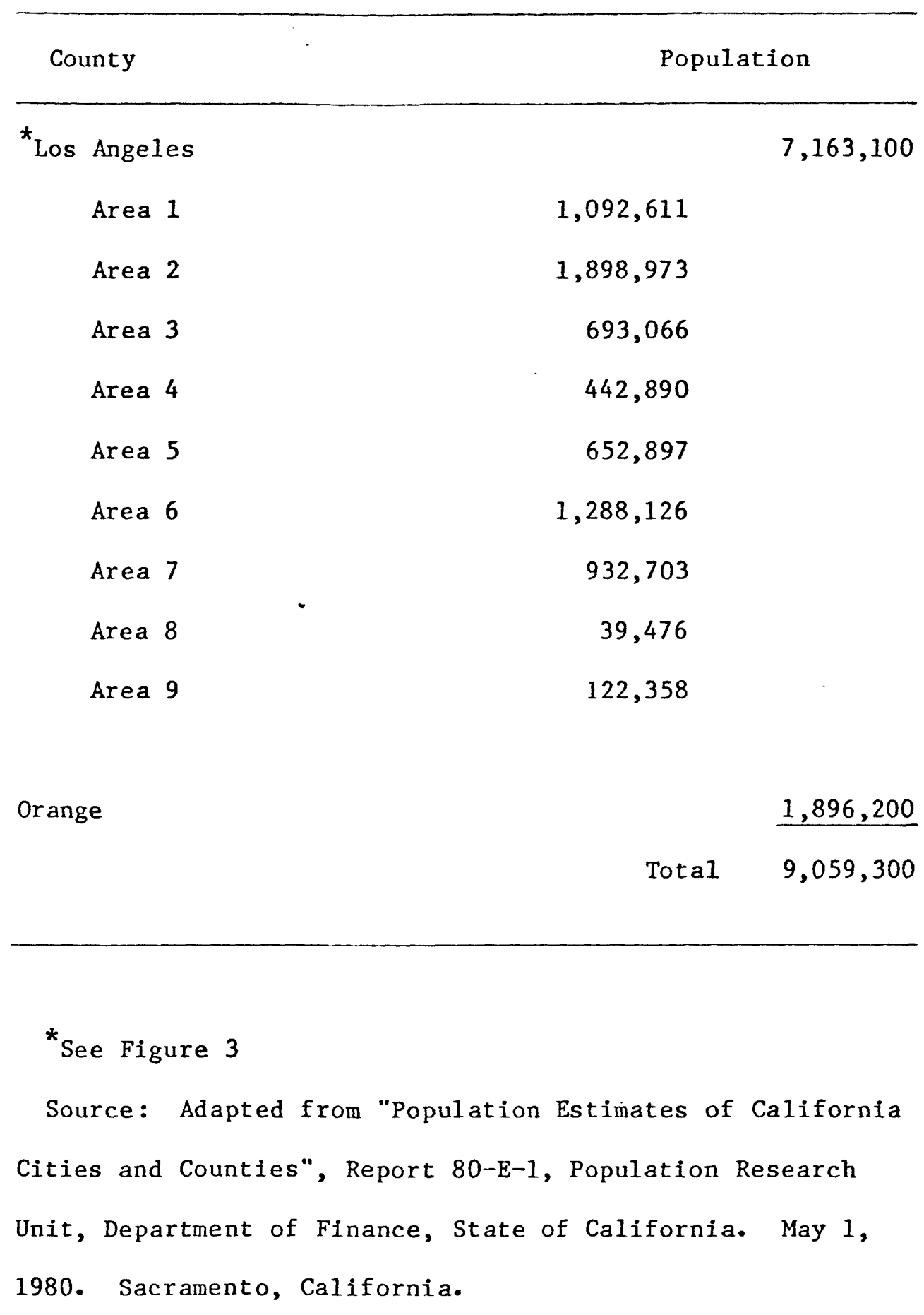


Table 3.--Population of cities in Los Angeles County--as of January 1, 1980.

City Population Area

City

Population

Area

\begin{tabular}{|c|c|c|c|c|c|}
\hline Alhambra & 62,500 & 5 & Lawndale & 23,750 & 3 \\
\hline Arcadia & 46,750 & 5 & Lomita & 20,000 & 3 \\
\hline Artesia & 15,300 & 6 & Long Beach & 345,300 & 4 \\
\hline Azusa & 26,650 & 7 & Los Angeles & $2,817,800$ & $1,2,3,4$ \\
\hline Avalon & 1,910 & - & Lynwood & 40,850 & 6 \\
\hline Baldwin Park & 47,950 & 7 & Manhattan Beach & 31,250 & 3 \\
\hline Be11 & 23,000 & 6 & Maywood & 18,500 & 6 \\
\hline Bellflower & 52,200 & 6 & Monrovia & 30,450 & 7 \\
\hline Be11 Gardens & 32,050 & 6 & Montebel1o & 49,900 & 6 \\
\hline Beverly Hills & 33,250 & 2 & Monterey Park & 52,300 & 5 \\
\hline Bradbury & 870 & 7 & Norwalf & 83,700 & 6 \\
\hline Burbank & 84,700 & 5 & Palmdale & 12,700 & 9 \\
\hline Carson & 79,100 & 6 & Palos Verdes Estates & 14,850 & 3 \\
\hline Cerritos & 51,200 & 6 & Paramount & 31,800 & 6 \\
\hline Claremont & 28,500 & 7 & Pasadena & 106,800 & 5 \\
\hline Commerce & 10,050 & 6 & Pico Rivera & 50,500 & 6 \\
\hline Compton & 75,700 & 6 & Pomona & 87,600 & 7 \\
\hline Covina & 33,250 & 7 & Rancho Palos Verdes & 38,200 & 3 \\
\hline Cudahy & 17,300 & 6 & Redondo Beach & 63,600 & 3 \\
\hline Culver City & 38,000 & 2 & Rolling Hills & 2,110 & 3 \\
\hline Downey & 86,700 & 6 & Rolling Hills Estate & 7,875 & 3 \\
\hline Duarte & 15,950 & 7 & Roseme ad . & 40,750 & 7 \\
\hline El Monte & 68,400 & 7 & San Dimas & 24,150 & 7 \\
\hline E1 Segundo & 15,100 & 3 & San Fernando & 15,250 & 1 \\
\hline Gardena & 44,650 & 3 & San Gabriel & 29,500 & 5 \\
\hline Glendale & 135,100 & 5 & San Marino & 13,450 & 5 \\
\hline Glendora & 37,100 & 7 & Santa Fe Springs & 15,350 & 6 \\
\hline Hawaiian Gardens & 10,200 & 6 & Santa Monica & 88,600 & 2 \\
\hline Hawthorne & 54,500 & 3 & Sierra Madre & 12,100 & 5 \\
\hline Hermosa Beach & 19,150 & 3 & Signal Hill & 6,550 & 4 \\
\hline Hidden Hills & 1,730 & 1 & South E1 Monte & 15,950 & 7 \\
\hline Huntington Park & $3 y, 800$ & 6 & South Gate. & 61,600 & 6 \\
\hline Industry & 630 & 7 & South Pasadena & 23,400 & 5 \\
\hline Inglewood & 91,200 & 3 & Temple City & 30,000 & 7 \\
\hline Irwindale & 750 & 7 & Torrance & 126,700 & 3 \\
\hline La Canada Flintridge & 19,300 & 5 & Vernon & 230 & 6 \\
\hline Lakewood & 80,200 & 6 & Walnut & 11,950 & 7 \\
\hline La Mirada & 44,100 & 6 & West Covina & 78,700 & 7 \\
\hline Lancaster & 48,100 & 9 & Whittier & 69,500 & 6 \\
\hline La Puente & 30,550 & 7 & Unincorporated & 942,000 & \\
\hline La Verne & 23,450 & 7 & & & \\
\hline & & & Total & $7,163,100$ & \\
\hline
\end{tabular}


Table 4.--Population of cities in Orange County

as of .1anuary 1,1980

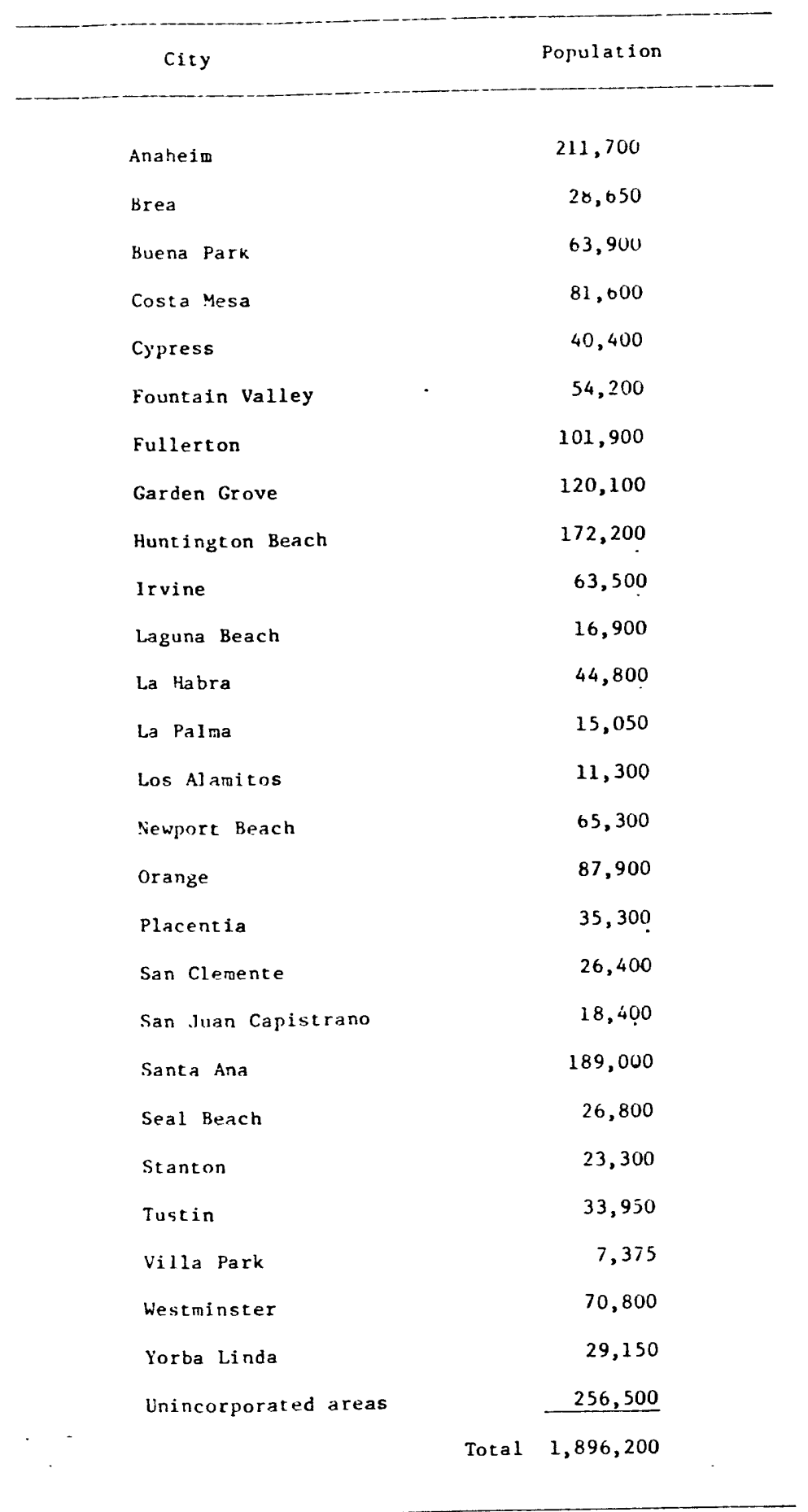

Source: Population Estimates of California Cities and Counties", Report $80 \mathrm{E}-1$, Population Research Unit, Department of Finance, State of California. May 1, 1980. Sacramento, Califurnia. 
Table 5.-population of selected cities in the 9 county

San Francisco study area as of January 1,1980

Population

Alageda County

Al ameda

Berkeley

Fremont

Hayriard

Oakland

San Leandro

Contra Costa County

Concord

Richmond

Walnut Creek

Marin County

Novato

San Rafael

Napa County

Napa

San Francisco City and County

San Mateo County

Daly City

Redwood City

San Mateo

South San Francisco

Santa Clara County

Mountain View

Palo Alto

San Jose

Santa Clara

Sunnyvale

Solano County

Fairfield

Vacaville

Vallejo

Sozoma County

Petaluma

Santa Rosa
58,100

69,200

110,400

127,300

95,100

327,300

67,100

105,100

70,800

54,600

42,550

44,300

48,800

642,900

74,000

56,000

80,300

49,650

58,200

54,100

610,400

85,000

107,200

42,450

75,400

32,750

78,300

Source: -Population Estimates of California Cities and Counties", Report 80 E-1, Population Research Unit, Department of Finance, State of California. May 1, 1980. Sacramento, California. 


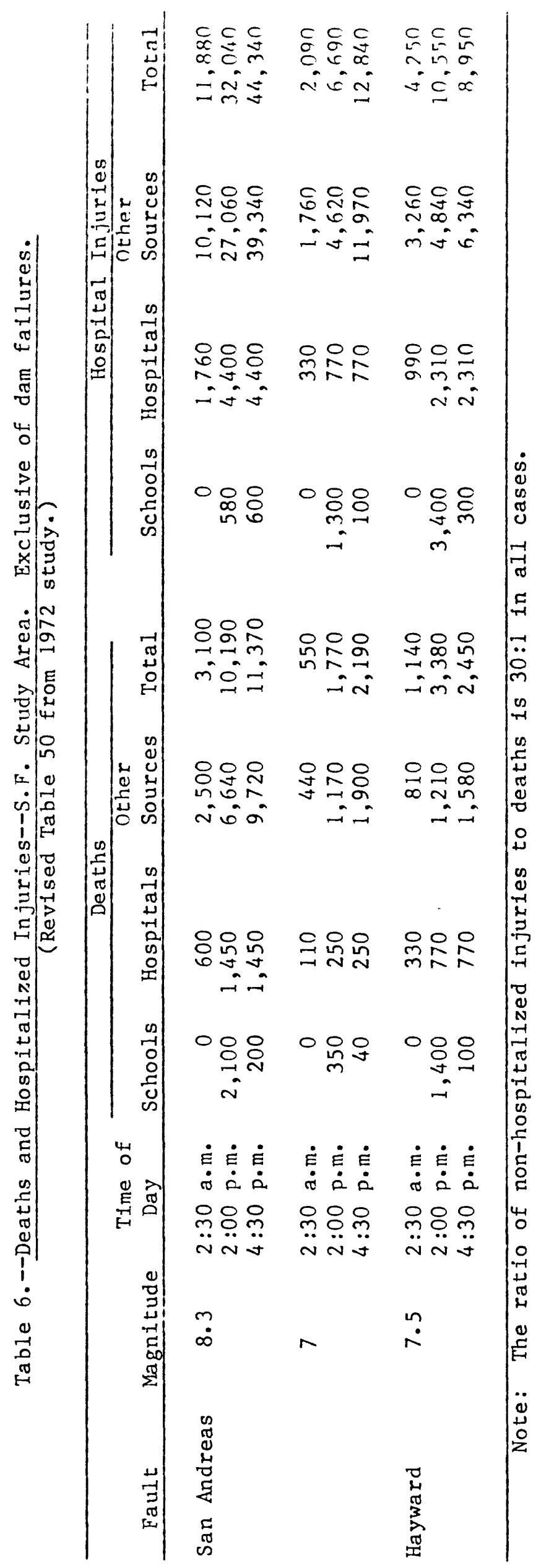




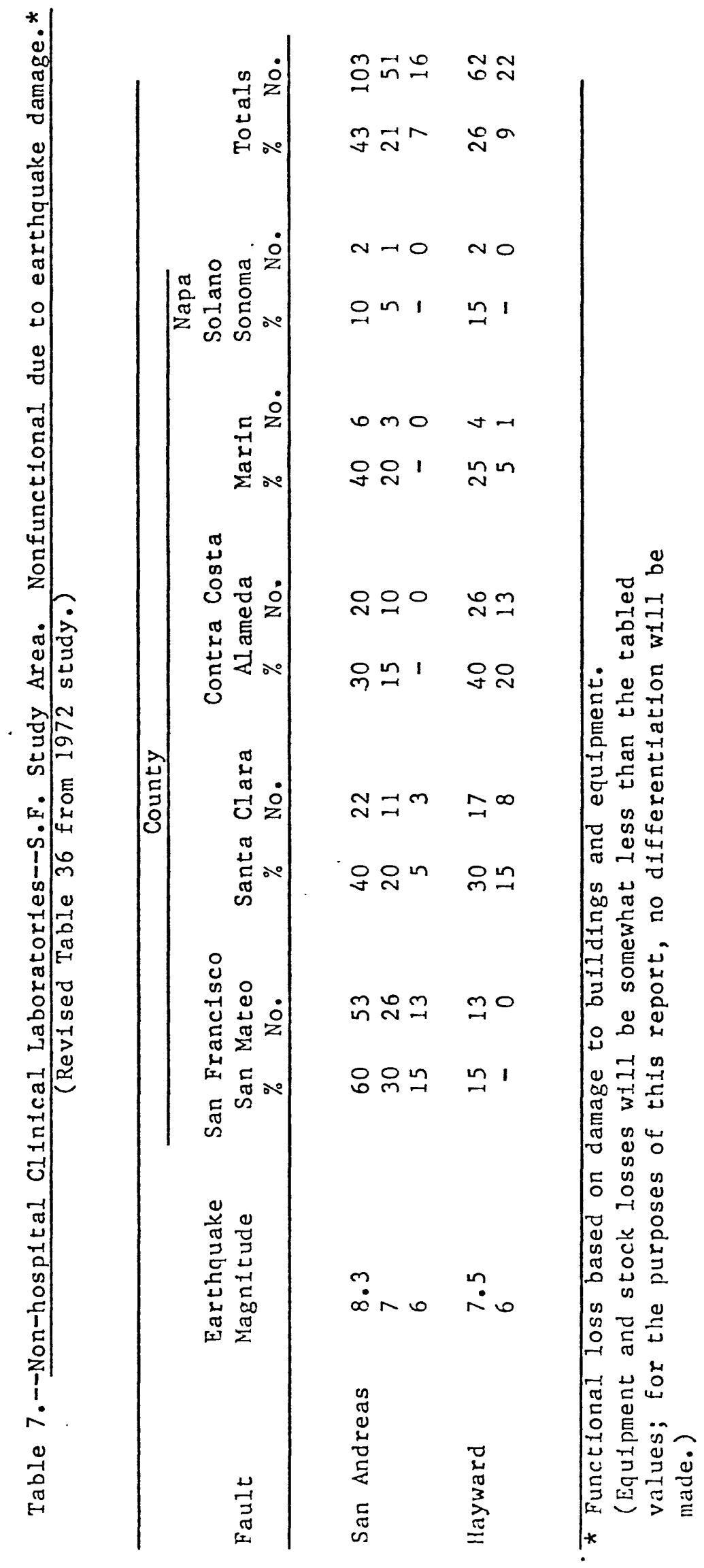




$$
\begin{aligned}
& \text { Table 8. - Transportation problems and their effects on medical } \\
& \text { personnel--San Francisco study area. Personnel assumed } \\
& \text { to be away from hospital or place of employment. } \\
& \text { (Revised Table } 25 \text { from the } 1972 \text { study) }
\end{aligned}
$$

\begin{tabular}{|c|c|c|c|c|c|}
\hline \multirow[b]{2}{*}{ Fault } & \multirow[b]{2}{*}{$\begin{array}{l}\text { Earthquake } \\
\text { magnitude }\end{array}$} & \multicolumn{2}{|c|}{$\begin{array}{c}\text { Percent } \\
\text { personnel absence }\end{array}$} & \multicolumn{2}{|c|}{$\begin{array}{l}\text { Physician and } \\
\text { surgeon absence }\end{array}$} \\
\hline & & $\begin{array}{l}{ }^{*} \text { Bridge } \\
\text { closure }\end{array}$ & $\begin{array}{l}{ }^{* *} \text { Other } \\
\text { problems }\end{array}$ & $\begin{array}{l}\text { *Bridge } \\
\text { closure }\end{array}$ & $\begin{array}{l}{ }^{* *} \text { Other } \\
\text { problems }\end{array}$ \\
\hline \multirow[t]{3}{*}{ San Andreas } & 8.3 & $6 \%$ & $2 \%$ & 720 & 240 \\
\hline & 7.0 & $3 \%$ & $1 \%$ & 360 & 120 \\
\hline & 6.0 & $0 \%$ & $0 \%$ & 0 & 0 \\
\hline \multirow[t]{2}{*}{ Hayward } & 7.5 & $2.5 \%$ & $2 \%$ & 300 & 240 \\
\hline & 6.0 & $0 \%$ & $0 \%$ & 0 & 0 \\
\hline
\end{tabular}

*Absence for 1 or more days.

**Absence for 1 or more hours, but not more than 8 hours. Due to failure of rapid transit systems, landslide, fallen overpasses, etc.

Note: The figures in this table apply to uninjured personne1; total absence figures must include injuries and deaths. 
Table 9.--Ambulance service impairment--San Francisco Bay Area (Revised Table 41 from the 1972 study)

\begin{tabular}{ccc}
$\begin{array}{l}\text { Earthquake } \\
\text { magnitude }\end{array}$ & $\begin{array}{c}\text { Number } \\
\text { of vehicles }\end{array}$ & $\begin{array}{r}\text { Percent } \\
\text { of total }\end{array}$ \\
\hline 8.3 & 37 & $12 \%$ \\
7 or 7.5 & 1 & $2 \%$ \\
6.0 & 1 & - \\
\hline
\end{tabular}

Note: This table applies to earthquakes on San Andreas or Hayward faults. The impairments due to San Andreas fault earthquakes will be on the west side of the Bay and impairments due to Hayward fault earthquakes will be on the east side of the Bay. 
Table 10.--Nursing homes and related facilities--San Francisco study area. One story structures which will be structurally unsafe. Functional impairments are not included.

(Revised Table 44 from the 1972 study)

\section{Lost beds by counties}

Fault Earthquake San Francisco magnitude and San Mateo

Santa Clara

Contra Costa and Alameda Marin

\begin{tabular}{lccccc}
\hline San Andreas & 8.3 & 777 & 490 & 174 & 26 \\
& 7.0 & 518 & 245 & 50 & - \\
Hayward & 6.0 & 259 & 490 & 1,305 & 65 \\
& 7.5 & 104 & 50 & 435 & - \\
\hline
\end{tabular}


Table 11.--Long Term Homeless--S.F. Study Area. Homeless due to potential dam failure must be added to these figures; see section on "Dams and Reservoirs" for locations.

(Revised Table 61 from the 1972 study.)

\begin{tabular}{|c|c|c|c|c|}
\hline County & $\begin{array}{l}\text { San An } \\
M=8.3\end{array}$ & $\frac{\text { as } \text { Fault }}{M=7}$ & $\begin{array}{c}\text { Hayward Fault } \\
M=7.5\end{array}$ & \\
\hline \multicolumn{5}{|l|}{ Al ameda } \\
\hline Wet season & 2,150 & 1,000 & 17,000 & \\
\hline Dry season & 2,150 & 1,000 & 26,500 & \\
\hline \multicolumn{5}{|l|}{ Contra Costa } \\
\hline Wet season & 350 & $\star$ & 9,700 & \\
\hline Dry season & 350 & * & 12,100 & \\
\hline \multicolumn{5}{|l|}{ Marin } \\
\hline Wet season & 1,500 & * & 3,800 & \\
\hline Dry season & 650 & * & 1,000 & \\
\hline \multicolumn{5}{|l|}{ Napa } \\
\hline Wet season & * & $\star$ & * & \\
\hline Dry season & * & * & * & \\
\hline \multicolumn{5}{|l|}{ San Francisco } \\
\hline Wet season & 14,800 & 5,500 & 4,200 & \\
\hline Dry season & 17,500 & 5,500 & 4,200 & \\
\hline \multicolumn{5}{|l|}{ San Mateo } \\
\hline Wet season & 9,600 & 9,600 & 700 & \\
\hline Dry season & 10,200 & 9,600 & 700 & , \\
\hline \multicolumn{5}{|l|}{ Santa Clara } \\
\hline Wet season & 4,000 & 1,800 & 12,600 & \\
\hline Dry season & 4,600 & 1,800 & 12,600 & \\
\hline \multicolumn{5}{|l|}{ Solano } \\
\hline Wet season & * & * & * & \\
\hline Dry season & * & * & * & \\
\hline \multicolumn{5}{|l|}{ Sonoma } \\
\hline Wet season & 400 & * & * & \\
\hline Dry season & 400 & * & * & \\
\hline
\end{tabular}

"Dry Season" includes homeless from landslide plus conflagration. 
Table 12.--Inventory of major hospitals--San Francisco study area with capacities of 99 beds or more

\begin{tabular}{|c|c|c|c|c|}
\hline \multirow[b]{2}{*}{ County } & & \multicolumn{3}{|c|}{ Type of hospital facility } \\
\hline & & $\begin{array}{c}\text { General } \\
\text { Total } \\
\text { No. bed cap. }\end{array}$ & \multicolumn{2}{|c|}{$\begin{array}{c}\text { Mental health } \\
\text { Total }\end{array}$} \\
\hline Alameda & 20 & 4,575 & -- & -- \\
\hline Contra Costa & 8 & 1,812 & - & -- \\
\hline Marin & 8 & 1,200 & 1 & 2,312 \\
\hline Napa & 3 & 1,088 & -- & -- \\
\hline San Francisco & 17 & 6,897 & see & note (1) \\
\hline San Mateo & 9 & 2,416 & -- & -- \\
\hline Santa Clara & 11 & 4,099 & 1 & 1,901 \\
\hline Solano & 4 & 537 & -- & -- \\
\hline Sonoma & $\underline{3}$ & 488 & 1 & $\underline{2,083}$ \\
\hline Totals: & 83 & 23,112 & 3 & 6,296 \\
\hline
\end{tabular}

Note:

(1) One mental health hospital reported previously in the 1972 NOAA San Francisco area study has been reduced to a 77 bed capacity and is therefore no
longer included in this study.

(2) Data includes university hospitals, university medical centers,
convalescent hospitals, etc.

Sources:

(a) Program - F1S127: Facilities Information System, March 26, 1980. Department of Health, State of California, Sacramento, California. (b) Office of the State Architect, Department of General Services, State of
California, Sacramento, California. 
Table 13.--General hospital bed loss - San Francisco study area with bed capacities of 99 or greater

\begin{tabular}{|c|c|c|c|c|c|}
\hline \multirow[b]{2}{*}{ County } & \multicolumn{3}{|c|}{ San Andreas Fault } & \multicolumn{2}{|c|}{ Hayward fault } \\
\hline & 8.3 & 7.0 & 6.0 & 7.5 & 6.0 \\
\hline Alameda & 549 & 105 & 5 & 2,050 & 1,354 \\
\hline Contra Costa & 54 & -- & --- & 176 & -- \\
\hline Marin & 681 & 523 & -- & 305 & --- \\
\hline Napa & 670 & 490 & 22 & 479 & --- \\
\hline San Francisco & 4,297 & 690 & -- & --- & --- \\
\hline San Mateo & 1,360 & 1,136 & 290 & 128 & -- \\
\hline Santa Clara & 3,240 & 1,452 & -- & 1,344 & -- \\
\hline Solano & 32 & -- & -- & 31 & 8 \\
\hline Sonoma & 1,543 & 722 & $=-$ & 337 & --- \\
\hline Totals: & 12,426 & 5,118 & 317 & 4,850 & 1,362 \\
\hline
\end{tabular}

Note: Does not include military or VA hospital bed losses. 
Table 14.--Deaths and Hospitalized Injuries--LA/Orange Study. Hospitalized injuries to deaths is $4: 1$, nonhospitalized injuries to deaths is $30: 1$. (Revised Table 57 from 1973 study.)

\begin{tabular}{|c|c|c|c|c|}
\hline \multirow[b]{2}{*}{ Fault } & \multirow[b]{2}{*}{ Area } & \multicolumn{3}{|c|}{ Deaths } \\
\hline & & $2: 30 \mathrm{a} \cdot \mathrm{m}$. & $2: 00 \mathrm{p} . \mathrm{m}$ & 4:30 p.m. \\
\hline San Andreas & Los Angeles County & & & \\
\hline \multirow[t]{12}{*}{$(M=8.3)$} & Area 1 & 380 & 880 & 960 \\
\hline & Area 2 & 620 & 5,690 & 6,260 \\
\hline & Area 3 & 160 & 330 & 370 \\
\hline & Area 4 & 100 & 520 & 570 \\
\hline & Area 5 & 230 & 680 & 750 \\
\hline & Area 6 & 450 & 1,030 & 1,040 \\
\hline & Area 7 & 340 & 840 & 930 \\
\hline & Area 8 & 5 & 15 & 15 \\
\hline & Area 9 & 60 & 140 & 150 \\
\hline & Sub-Total & 2,345 & 10,125 & 11,045 \\
\hline & Orange County & 620 & 1,310 & 1,450 \\
\hline & Total & 2,965 & 11,435 & 12,495 \\
\hline Newport-Inglewood & Los Angeles County & & & \\
\hline \multirow[t]{11}{*}{$(M=7.5)$} & $\begin{array}{c}\text { Area } 1 \\
\text { Area } 2\end{array}$ & $\begin{array}{l}510 \\
950\end{array}$ & $\begin{array}{r}1,130 \\
10,190\end{array}$ & $\begin{array}{r}1,250 \\
11,200\end{array}$ \\
\hline & Area 3 & 350 & 760 & 840 \\
\hline & Area 4 & 240 & 1,790 & 1,970 \\
\hline & Area 5 & 280 & 650 & 720 \\
\hline & Area 6 & 640 & 1,400 & 1,540 \\
\hline & Area 7 & 400 & 770 & 850 \\
\hline & Area 8 & 10 & 20 & 20 \\
\hline & Area 9 & 50 & 90 & 100 \\
\hline & Sub-Total & 3,430 & 16,800 & 18,490 \\
\hline & Or ange County & 950 & 2,060 & 2,265 \\
\hline & Total & 4,380 & 18,860 & 20,755 \\
\hline
\end{tabular}


Table 15.--Non-hospital Clinical Laboratories--LA/Orange study. Nonfunctional due to earthquake damage.*

$$
\text { (Revised Table } 42 \text { from } 1973 \text { report.) }
$$

\begin{tabular}{|c|c|c|c|c|}
\hline \multirow[b]{2}{*}{ County } & \multicolumn{2}{|c|}{$\begin{array}{l}\text { San Andreas Fault } \\
\text { Magnitude }=8.3\end{array}$} & \multicolumn{2}{|c|}{$\begin{array}{l}\text { Newport-Inglewood Fault } \\
\text { Magnitude }=7.5\end{array}$} \\
\hline & Number & Percentile & Number & Percentile \\
\hline \multicolumn{5}{|c|}{ Los Angeles } \\
\hline Area 1 & 22 & $40 \%$ & 42 & $75 \%$ \\
\hline Area 2 & 53 & $30 \%$ & 140 & $80 \%$ \\
\hline Area 3 & 2 & $10 \%$ & 15 & $80 \%$ \\
\hline Area 4 & 3 & $10 \%$ & 23 & $80 \%$ \\
\hline Area 5 & 24 & $50 \%$ & 26 & $55 \%$ \\
\hline Area 6 & 20 & $40 \%$ & 41 & $80 \%$ \\
\hline Area 7 & 19 & $70 \%$ & 8 & $30 \%$ \\
\hline Area 8 & 0 & $0 \%$ & 0 & $0 \%$ \\
\hline Area 9 & 7 & $80 \%$ & 1 & $10 \%$ \\
\hline Sub-Total & 150 & $36 \%$ & 296 & $72 \%$ \\
\hline Orange & 28 & $25 \%$ & 78 & $70 \%$ \\
\hline Totals & 178 & $34 \%$ & 374 & $71 \%$ \\
\hline
\end{tabular}


Table 16.--Deaths to health manpower--Los Angeles/Orange study (Revised Table 27 from 1973 report)

\begin{tabular}{|c|c|c|c|c|}
\hline \multirow[b]{2}{*}{ County } & \multicolumn{2}{|c|}{$\begin{array}{c}\text { San Andreas fault } \\
\text { magnitude }=8.3\end{array}$} & \multicolumn{2}{|c|}{$\begin{array}{l}\text { Newport-Inglewood fault } \\
\text { magnitude }=7.5\end{array}$} \\
\hline & $\begin{array}{c}\text { Physicians } \\
\text { and } \\
\text { surgeons }\end{array}$ & $\begin{array}{l}\text { Registered } \\
\text { nurses }\end{array}$ & $\begin{array}{c}\text { Physicians } \\
\text { and } \\
\text { surgeons }\end{array}$ & $\begin{array}{c}\text { Registered } \\
\text { nurses }\end{array}$ \\
\hline \multicolumn{5}{|l|}{ Los Angeles } \\
\hline Area 1 & 1 & 5 & 2 & 7 \\
\hline Area 2 & 20 & 36 & 35 & 65 \\
\hline Area 3 & 1 & 2 & 1 & 5 \\
\hline Area 4 & 1 & 3 & 5 & 12 \\
\hline Area 5 & 2 & 5 & 2 & 3 \\
\hline Area 6 & 1 & 6 & 1 & 8 \\
\hline Area 7 & 1 & 5 & 1 & 5 \\
\hline Area 8 & 0 & 0 & 0 & 0 \\
\hline Area 9 & 0 & 1 & 0 & 1 \\
\hline Sub-total & 27 & 63 & 47 & 106 \\
\hline Orange & $\underline{2}$ & 8 & 2 & 11 \\
\hline Totals & 29 & 71 & 49 & 117 \\
\hline
\end{tabular}




\section{Table 17.--Ambulance service impairment--Los Angeles/Orange study \\ (Revised Table 47 from 1973 report)}

\begin{tabular}{|c|c|c|c|c|c|}
\hline \multirow[b]{3}{*}{ County } & \multirow{3}{*}{$\begin{array}{c}\text { Services } \\
\text { parked } \\
\text { inside* }\end{array}$} & \multicolumn{4}{|c|}{ Services not functional } \\
\hline & & \multicolumn{2}{|c|}{$\begin{array}{l}\text { San Andreas fault } \\
\text { magnitude }=8.3\end{array}$} & \multicolumn{2}{|c|}{$\begin{array}{l}\text { Newport-Inglewood fault } \\
\text { magnitude }=7.5\end{array}$} \\
\hline & & $\begin{array}{l}\text { Number of } \\
\text { services }\end{array}$ & $\begin{array}{c}\text { Percent of } \\
\text { total services }\end{array}$ & $\begin{array}{l}\text { Number of } \\
\text { services }\end{array}$ & $\begin{array}{c}\text { Percent of } \\
\text { total services }\end{array}$ \\
\hline Los Angeles & & & & & \\
\hline Area 1 & 4 & 1 & N.C. ${ }^{* *}$ & 1 & N.C. ${ }^{* *}$ \\
\hline Area 2 & 9 & 1 & & 4 & \\
\hline Area 3 & 5 & 0 & & 1 & \\
\hline Area 4 & 5 & 0 & & 1 & \\
\hline Area 5 & 7 & 0 & & 1 & \\
\hline Area 6 & 6 & 1 & & 3 & \\
\hline Area 7 & 4 & 1 & & 0 & \\
\hline Area 8 & 1 & 0 & & 0 & \\
\hline Area 9 & 5 & 1 & & $\underline{.}$ & 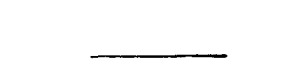 \\
\hline Sub-total & 46 & 5 & $4 \%$ & 11 & $8 \%$ \\
\hline Orange & 11 & 1 & $4 \%$ & 2 & $7 \%$ \\
\hline Totals & 57 & 6 & $4 \%$ & 13 & $8 \%$ \\
\hline
\end{tabular}

* Based on $40 \%$ of all services in study area which have ambulances parked inside of buildings.

** "Not computed" for 9 Areas in Los Angeles County as individual percentages are negligible. 
Table 18.--Nursing homes--Los Angeles/Orange study

(Revised of Table 50 from 1973 report)

\begin{tabular}{|c|c|c|}
\hline \multirow[t]{2}{*}{1} & \multicolumn{2}{|c|}{ Magnitude of postulated earthquake } \\
\hline & $\begin{array}{l}\text { San Andreas fault } \\
\text { magnitude }=8.3\end{array}$ & $\begin{array}{c}\text { Newport-Inglewood fault } \\
\text { magnitude }=7.5\end{array}$ \\
\hline County & Lost beds & Lost beds \\
\hline Los Angeles & & \\
\hline Area 1 & 240 & 480 \\
\hline Area 2 & 328 & 984 \\
\hline Area 3 & 128 & 257 \\
\hline Area 4 & 148 & 296 \\
\hline Area 5 & 142 & 142 \\
\hline Area 6 & 204 & 408 \\
\hline Area 7 & 347 & 178 \\
\hline Area $8^{*}$ & -- & -- \\
\hline Area 9 & 119 & 24 \\
\hline Sub-total & 1,656 & 2,769 \\
\hline Orange & 300 & 600 \\
\hline Totals & 1,956 & 3,369 \\
\hline
\end{tabular}

${ }^{*}$ None in Area 8. 
Table 19.--Long term homeless--Los Angeles/Orange

study exclusive of dam failure and fire.

(Update of Table 105 from 1973 report)

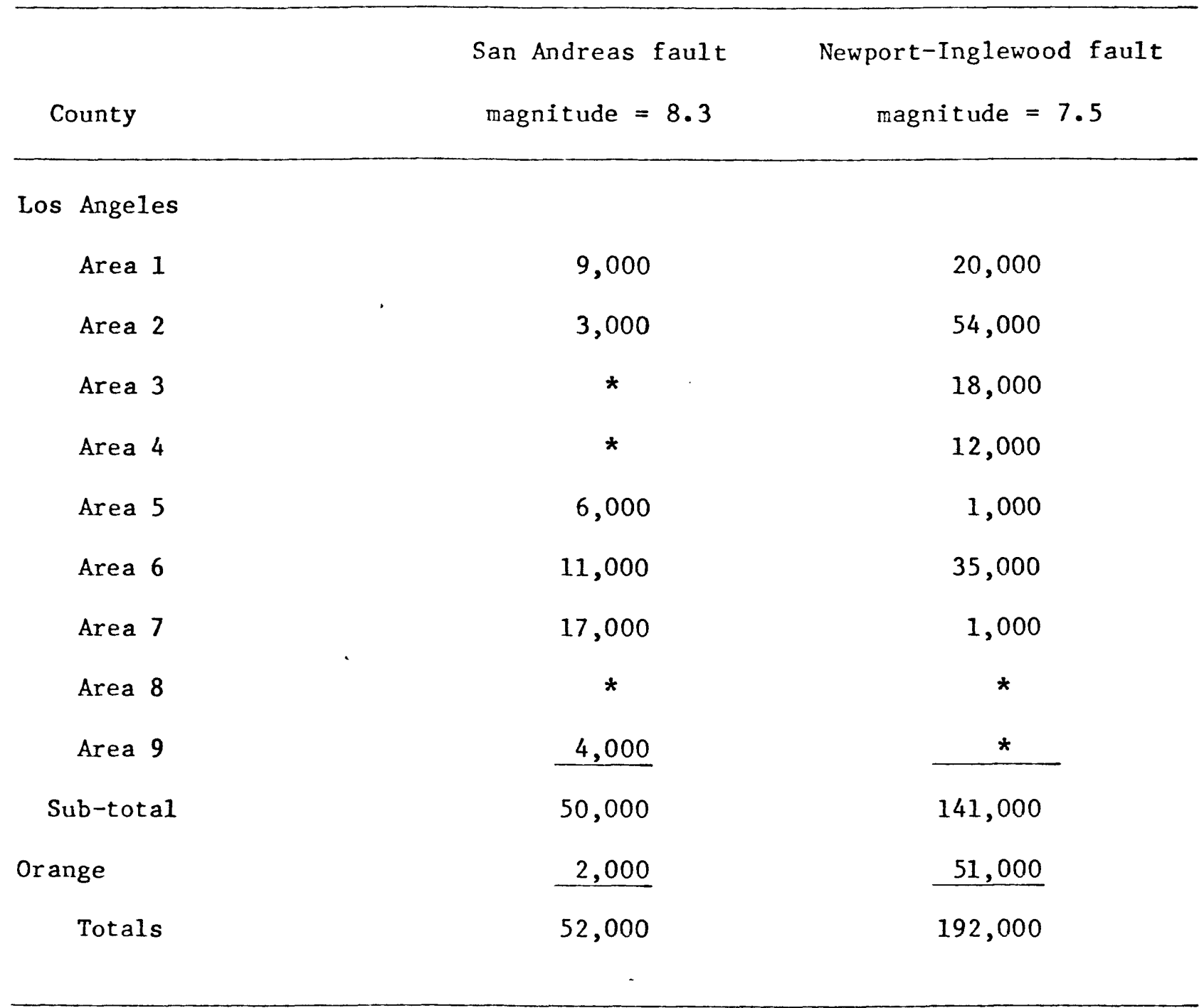

${ }^{\star}$ Negligible 
Table 20.--Inventory of major hospitals--Los Angeles study area with capacities of 99 beds or more

\begin{tabular}{|c|c|c|c|c|}
\hline \multirow[b]{2}{*}{ County } & \multicolumn{4}{|c|}{ Type of hospital facility } \\
\hline & \multicolumn{2}{|c|}{$\begin{array}{c}\text { General } \\
\text { Total }\end{array}$} & \multicolumn{2}{|c|}{$\begin{array}{c}\text { Mental health } \\
\text { Total }\end{array}$} \\
\hline \multicolumn{5}{|l|}{ Los Angeles } \\
\hline Area 1 & 18 & 3,771 & -- & --- \\
\hline Area 2 & 32 & 11,339 & 1 & 166 \\
\hline Area 3 & 10 & 2,978 & -- & --- \\
\hline Area 4 & 9 & 2,982 & -- & --- \\
\hline Area 5 & 10 & 2,852 & - & $-\cdots$ \\
\hline Area 6 & 18 & 3,753 & 1 & 1,078 \\
\hline Area 7 & 11 & 2,401 & 1 & 1,902 \\
\hline Area 8 & 1 & 126 & -- & -- \\
\hline Area 9 & 5 & 792 & - & --- \\
\hline Sub-totals & 114 & 30,994 & 3 & 3,146 \\
\hline Orange & 32 & 6,780 & 1 & 1,690 \\
\hline Riverside & 25 & 3,843 & -- & --- \\
\hline San Bernardino & 29 & 4,946 & 1 & 1,410 \\
\hline Ventura & 11 & 1,747 & 1 & 1,751 \\
\hline Totals: & 211 & 48,310 & 6 & 7,997 \\
\hline
\end{tabular}

Note: Data includes university hospitals, university medical centers, - convalescent hospitals, etc.

Sources:

(a) Program - F1S127: Facilities Information System, March 26, 1980. Department of Health, State of California, Sacramento, California.

(b) Office of State Architect, Department of General Services, State of California, Sacramento, California. 


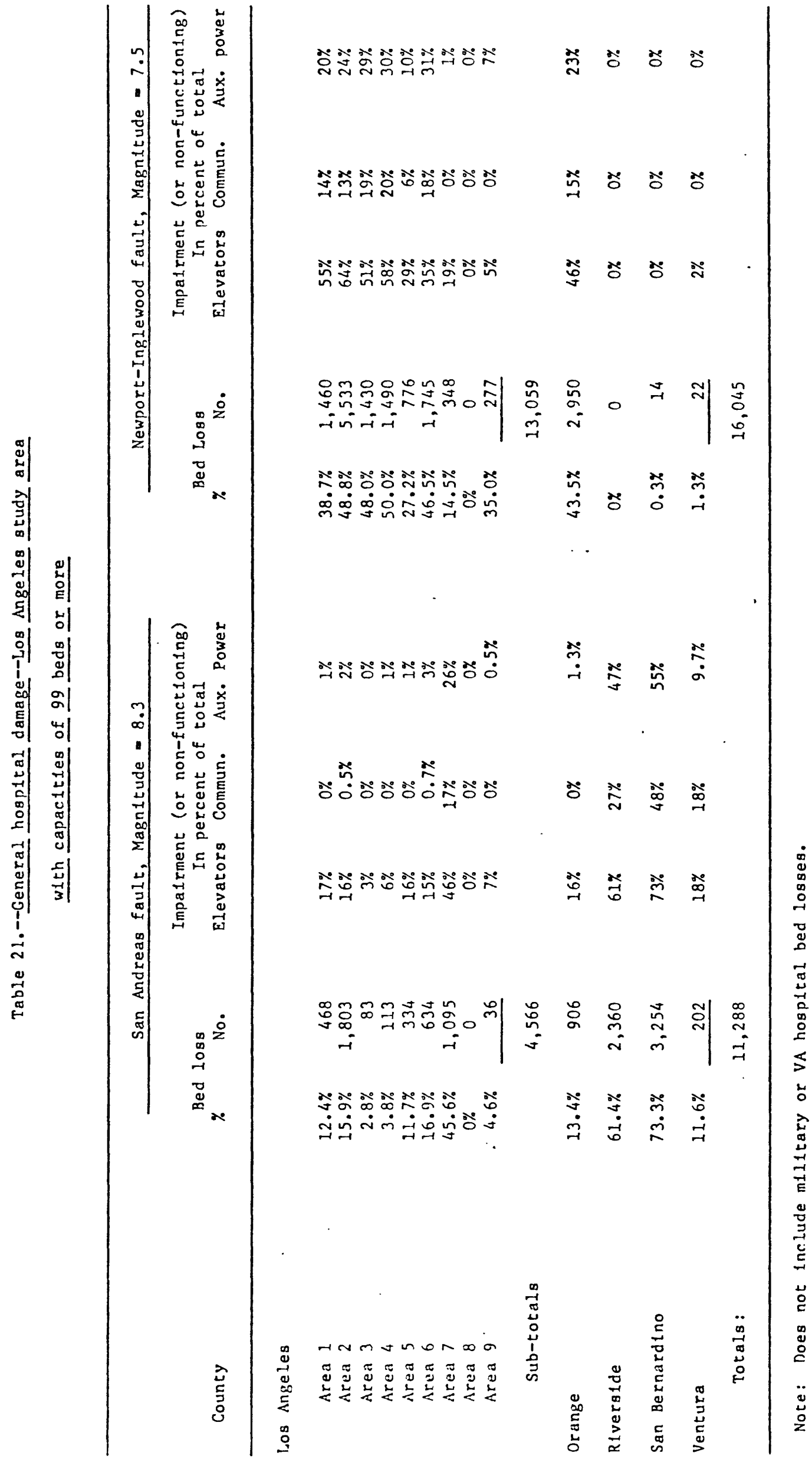




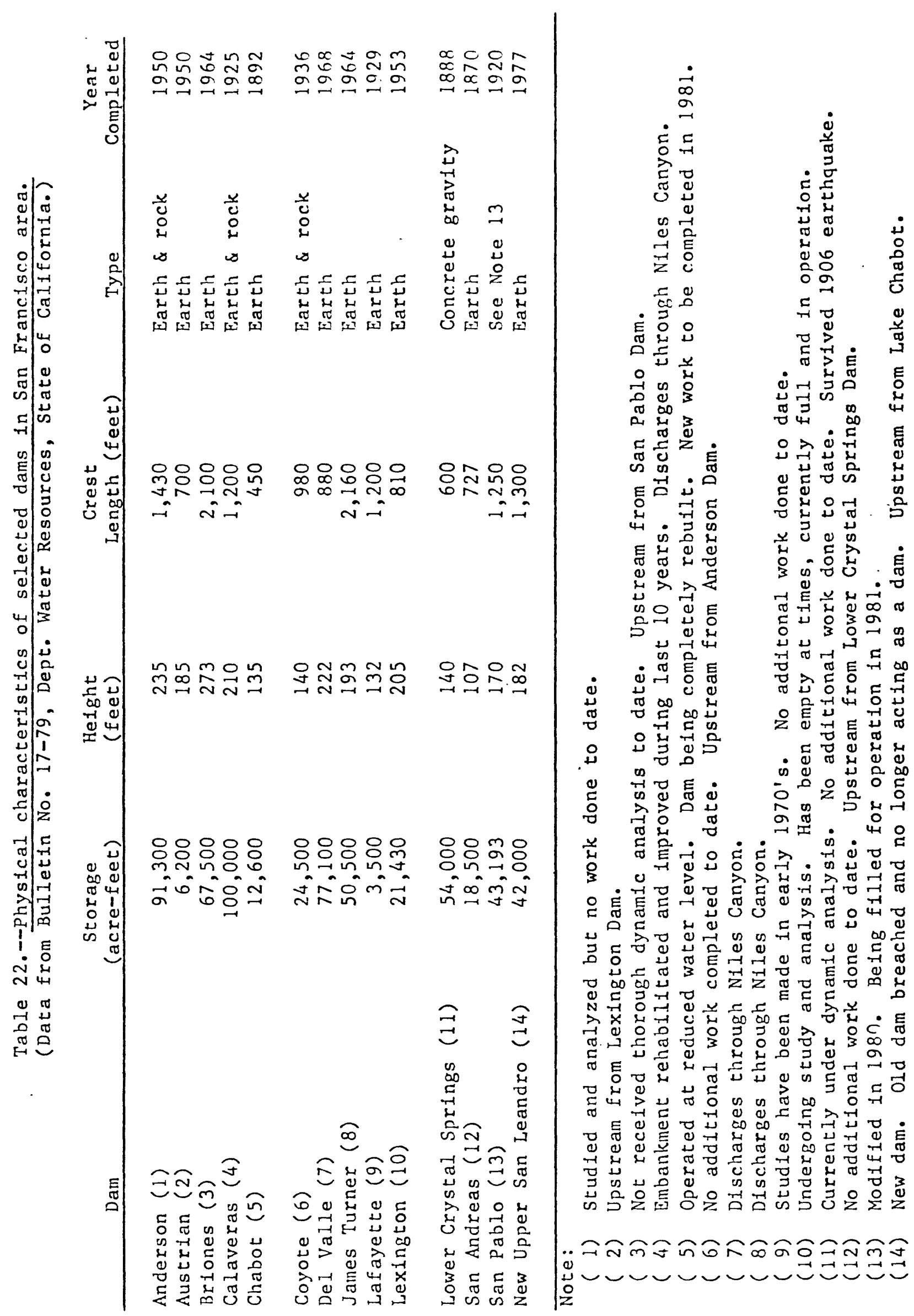




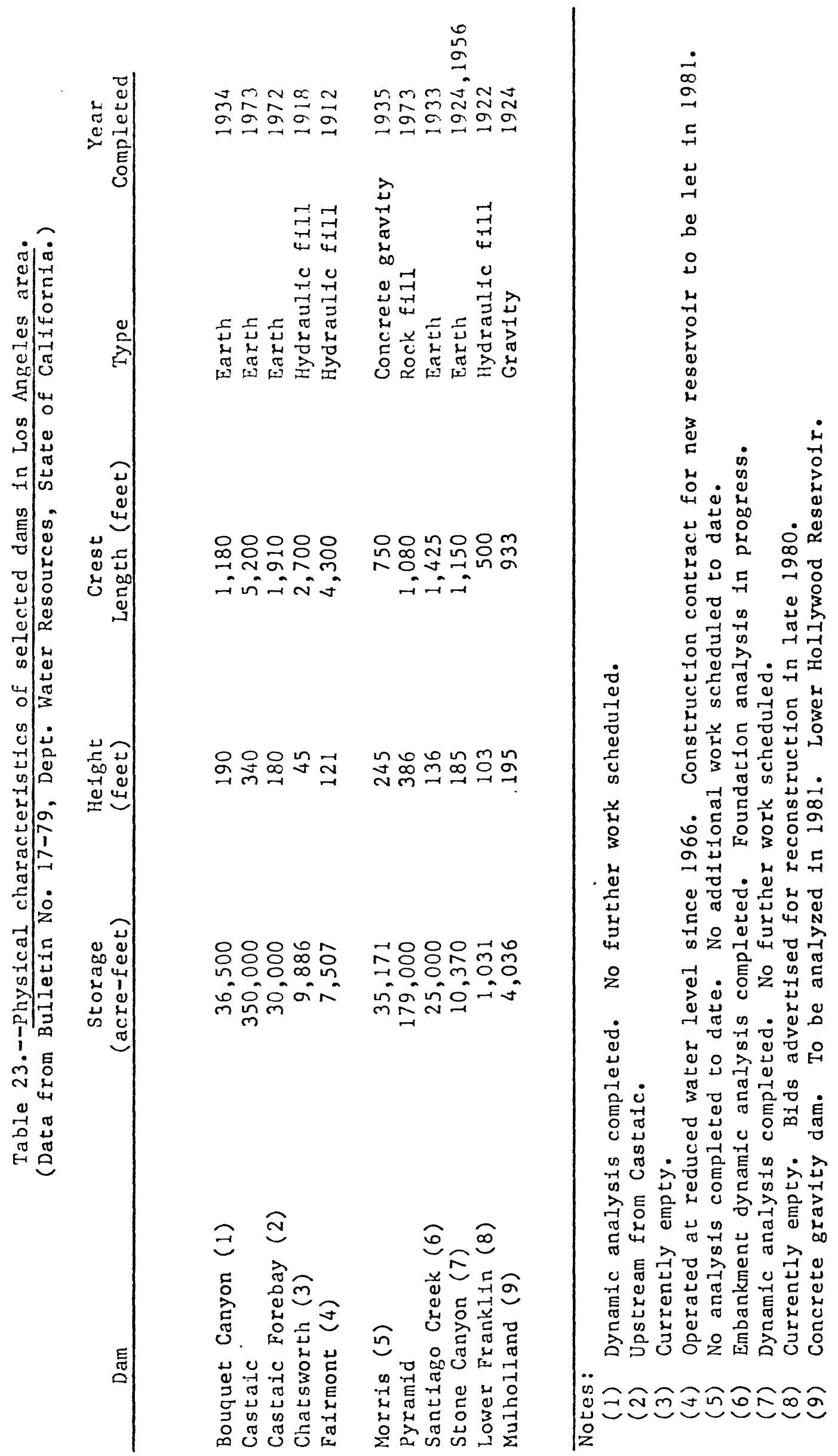




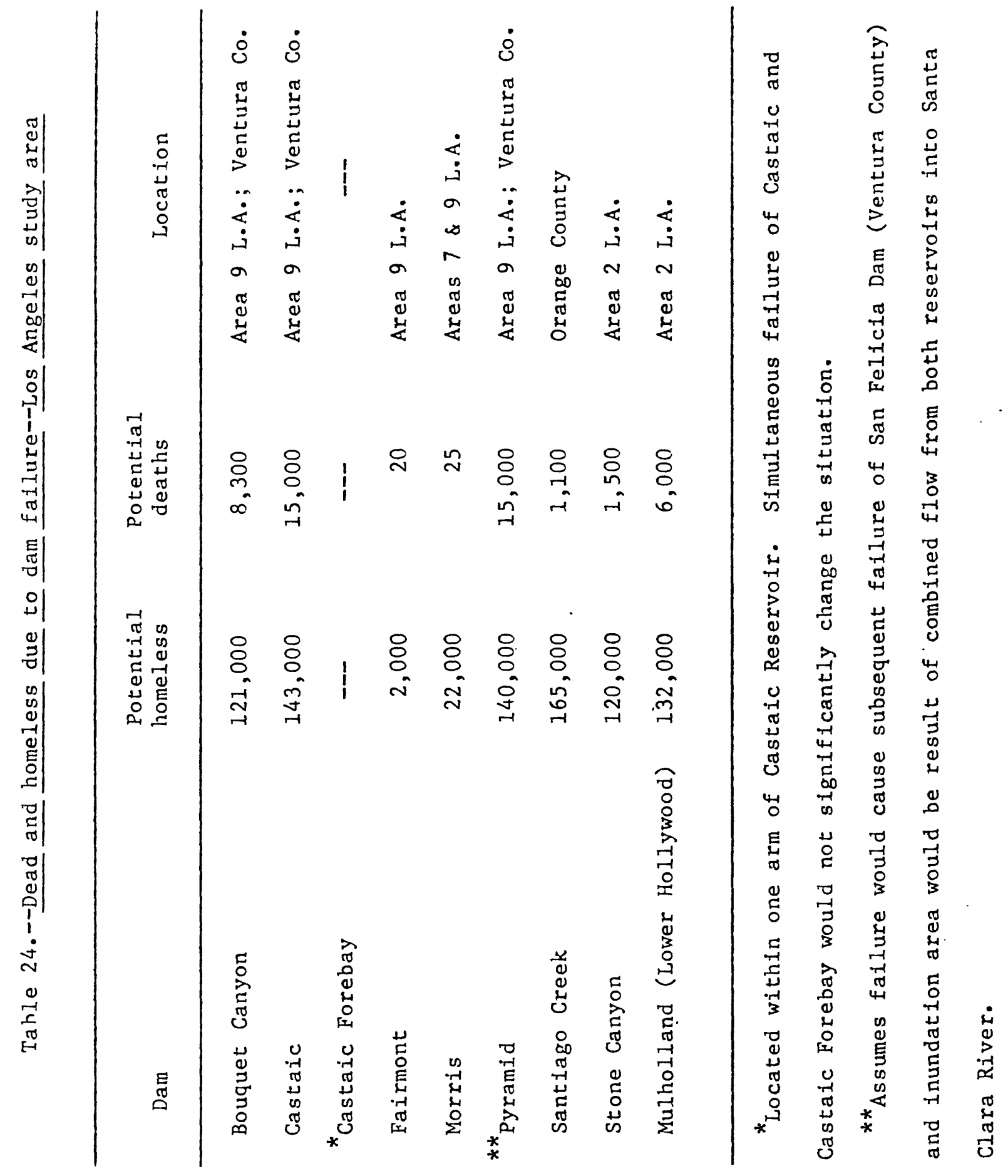




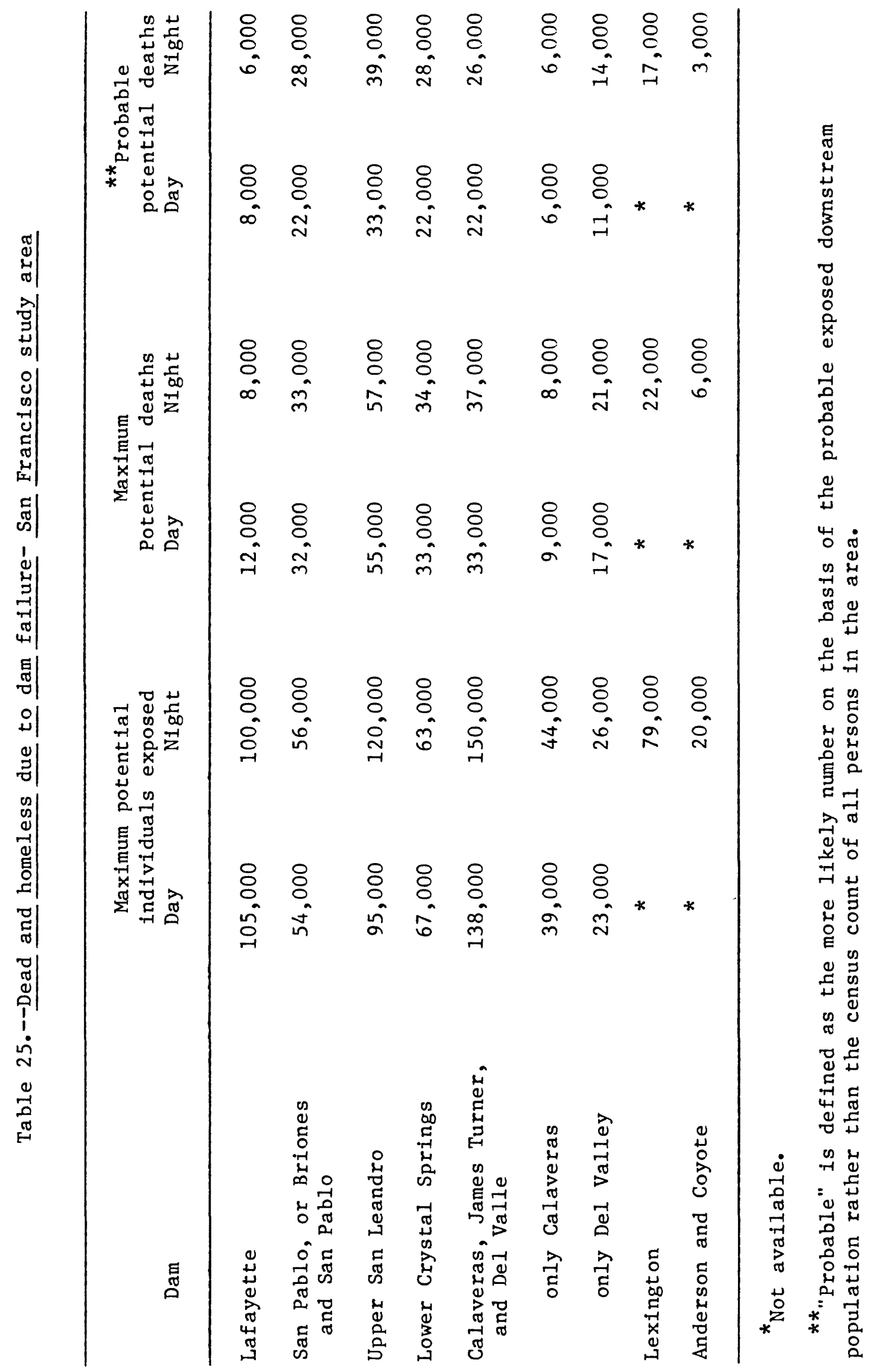


Table 26.--Monetary losses. Losses in millions of 1980 dollars

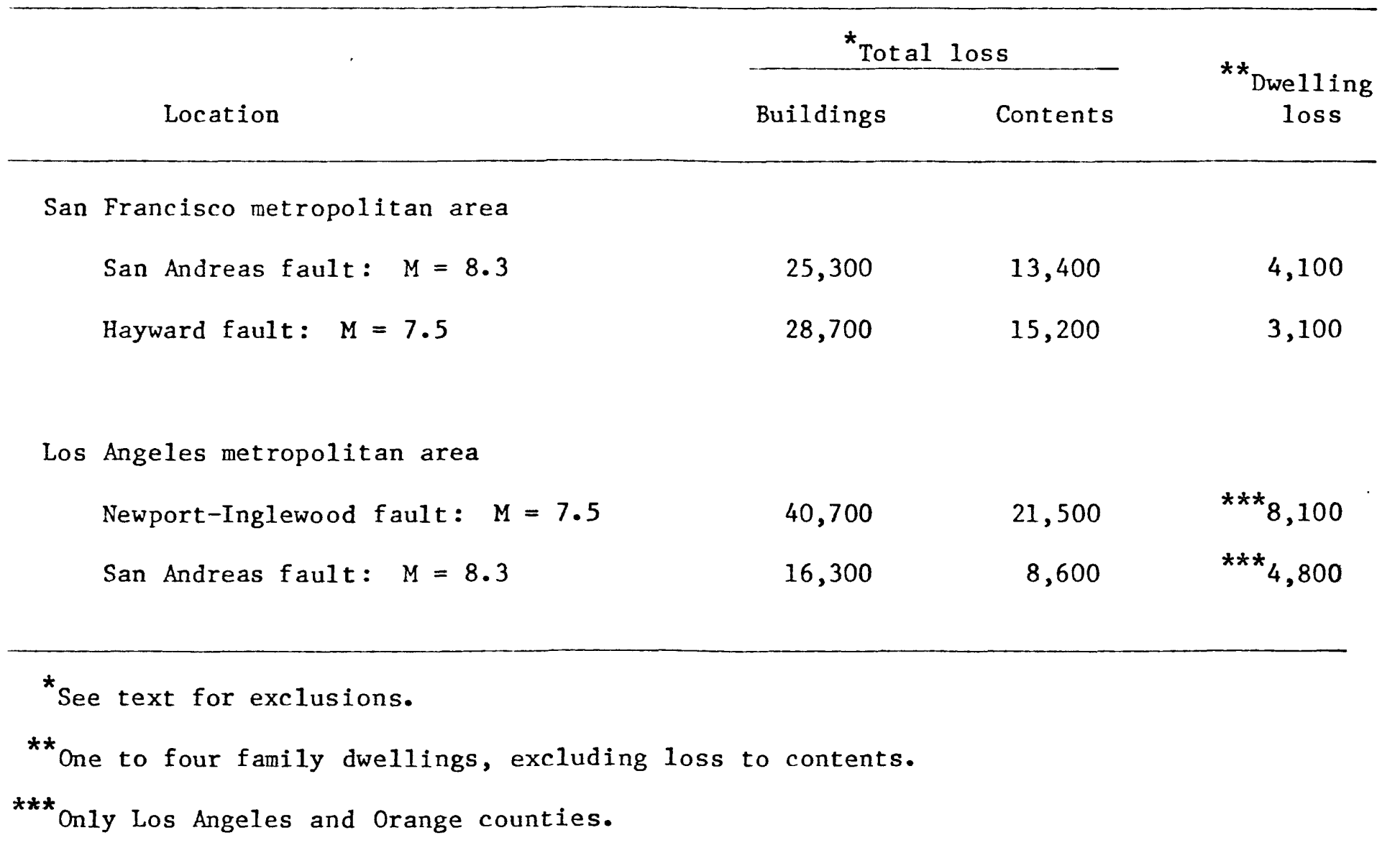


Table 27.--Estimated annual earthquake losses* to one to four family dwellings in selected counties and areas of California

\section{Areas}

Losses (1980)

(millions of dollars)

Nine San Francisco Bay Area Counties**

$\$ 115$

Los Angeles and Orange Counties

136

Entire State

324

*Losses are in 1980 dollars, where losses are defined as the replacement cost of the dwellings. Losses are those associated with ground shaking only.

** Marin, Sonoma, Napa, Solano, San Francisco, Santa Clara, Contra Costa, Alameda, and San Mateo Counties. 